Scholarship Repository

University of Minnesota Law School

Articles

Faculty Scholarship

2007

\title{
Crime, Criminal Justice, and Criminology in the Netherlands
}

\author{
Michael Tonry \\ University of Minnesota Law School, tonry001@umn.edu
}

Catrien Bijleveld

Follow this and additional works at: https://scholarship.law.umn.edu/faculty_articles

Part of the Law Commons

\section{Recommended Citation}

Michael Tonry and Catrien Bijleveld, Crime, Criminal Justice, and Criminology in the Netherlands, 35 CRIME \& JUST. 1 (2007), available at https://scholarship.law.umn.edu/faculty_articles/496.

This Article is brought to you for free and open access by the University of Minnesota Law School. It has been accepted for inclusion in the Faculty Scholarship collection by an authorized administrator of the Scholarship Repository. For more information, please contact lenzx009@umn.edu. 


\section{Micbael Tonry and Catrien Bijleveld}

\section{Crime, Criminal Justice, and Criminology in the Netherlands}

The Netherlands is particularly appropriate as the subject of the first Crime and fustice volume to focus on a single European country or region. Its criminal justice policies have long been well known, its social policies and problems receive widespread international attention, and it has among the longest and strongest research traditions in criminology in Europe.

For nearly fifty years after World War II, the Netherlands was commonly portrayed as having the most liberal and humane criminal justice system among Western countries (e.g., Downes 1988). In the early twenty-first century it is sometimes viewed as having one of Europe's most severe criminal justice systems, perhaps following that of England and Wales (Downes 2007). By the end of 2006, many judges and lawyers were complaining that the criminal law system had become overheated, with criminalization of behavior increasing and procedural rights of defendants decreasing (Ippel and Heeger 2006).

During most of the postwar period, the Netherlands exemplified (at least to outsiders) generous social welfare policies, sensible criminal justice policies, and tolerant social attitudes. Drug policies were generally seen as pragmatic and lenient, as were abortion laws.

Social policies relating to ethnic minority groups seemed to be working. Immigrants from Indonesia after its independence were assimilated

Errors of analysis or fact in this introduction are alas our own, but we are grateful to the following people who kindly read an earlier draft and helped us avoid some errors and tried to save us from others: Gerben Bruinsma, Ybo Buruma, Henk van de Bunt, David Downes, Edward Kleemans, Godfried Engbersen, René van Swaaningen, and Frank Weerman.

(C) 2007 by The University of Chicago. All rights reserved. $0192-3234 / 2007 / 0035-0012 \$ 10.00$ 
almost without notice. Subsequent waves of immigrants came from former Dutch colonies in South America and the Caribbean, and especially from Turkey and Morocco, as guest workers and their families. Most recently, sizable numbers of asylum seekers and their families came to live in the Netherlands. For the most part, Dutch policies supported maintenance of immigrants' cultural traditions and did not pressure them to assimilate.

By the end of the twentieth century, and early in the twenty-first, changes were becoming evident. Welfare provision had become less generous, criminal justice policies hardened, and policies concerning immigrants and refugees became stricter. Right-wing political parties and anti-immigrant politicians exemplified widespread feelings that Dutch multiculturalism had failed (Buruma, in this volume; Engbersen, van der Leun, and de Boom, in this volume).

The Netherlands has long been internationally prominent in criminology and criminal justice research. The Ministry of Justice Research and Documentation Centre (the WODC, its acronym in Dutch) is among the best-known government research agencies in Europe and among the most internationalist. The International Crime Victims Survey (e.g., van Kesteren, Mayhew, and Nieuwbeerta 2001), the International Self-Report Delinquency Study (e.g., Junger-Tas, Haen Marshall, and Ribeaud 2003), and the European Sourcebook of Crime and Criminal fustice Statistics (e.g., Aebi et al. 2006) have all at various times found their homes there. Widespread English fluency has meant that Dutch research is well known elsewhere. The Netherlands Institute for the Study of Crime and Law Enforcement (NSCR, another Dutch acronym), jointly supported by the National Organization for Scientific Research, the Ministry of Justice, and Leiden University, is one of Europe's few independent, stably funded research institutes specializing in mid- and long-term fundamental research on crime and the justice system. Dutch scholars were prominent in the creation in 2000 of the European Society of Criminology and in its subsequent development.

The essays in this volume discuss the development of Dutch criminal justice policies and research and provide comprehensive overviews of research areas in which Dutch research is especially strong and Dutch researchers are especially prolific. In this essay we provide a backdrop to what follows. Sections I-III provide thumbnail sketches of the country, its population, and its criminal justice system. The Netherlands is 
densely populated, particularly in the West. Big-city populations, especially among the young, are increasingly non-Dutch. The economy is strong, unemployment rates are low, and income inequality is relatively modest (but growing). As in most of western Europe, criminal justice officials are neither elected nor politically selected, and most are career civil servants.

Section IV sketches crime and punishment trends. Dutch crime trends do not stand out in a European context. Dutch incarceration trends do. Crime trends-broadly rising from the 1970s through the 1990s and stabilizing or falling since then (for property offenses, falling, for sure; the evidence is less clear concerning violence)-parallel those of most western European countries (e.g., Bijleveld and Smit 2005; Aebi et al. 2006). However, they stand out concerning imprisonment: incarceration rates per 100,000 have increased continuously since the early 1970s, when they were the lowest in Europe. The threedecade rate of increase is by a wide margin the largest in Europe, rivaling that of the United States during the same period (though from a much lower starting point).

Section V, necessarily impressionistic and idiosyncratic, is our effort to generalize about criminological and criminal justice research in the Netherlands. Research on organized crime, organizational crime, juvenile delinquency, some kinds of violent offending, and ethnicity and crime is especially rich. Research on criminal justice system operations-police, prosecutors, courts, probation, and prisons-and on women and crime, costs of crime, and cost- and treatment-effectiveness is comparatively meager. The strategic implications for research priorities and funding are straightforward.

\section{The Netherlands ${ }^{1}$}

The Netherlands, small and densely populated, has historically been perceived as a tolerant and at times permissive country. The Dutch have long been known for their practicality and their trading spirit. They have for as long been and still are commonly characterized as down-to-earth, frugal, and unostentatious. Wim Kok often bicycled to

\footnotetext{
${ }^{1}$ Unless otherwise indicated, demographic, economic, social, and other statistical data used in this and the following section were obtained from the Netherlands' Central Bureau of Statistics (http://www.cbs.nl).
} 
work in The Hague and to visit the queen when he was prime minister, as did Piet Hein Donner when he was minister of justice.

Many a dissident writer printed his books in the Netherlands beginning in the late Middle Ages (e.g., Bayle, Erasmus, Luther, Spinoza). Waves of migrants and refugees fleeing persecution settled there, notably including Sephardic Jews in the sixteenth and seventeenth centuries, French Huguenots in the seventeenth and eighteenth centuries, and many former residents (mainly of mixed descent) from the former Dutch East Indies. The Puritans who settled Massachusetts Bay Colony, the first permanent English-speaking settlement in America, sheltered in Leiden for a decade to escape persecution in England before leaving for America.

Many liberal social policies remain. Dutch drug policy is famous for its pragmatism and permissiveness and for its irreconcilable elements (users may legally buy small amounts of soft drugs in designated shops, but there are no legal markets in which shop owners may buy their supplies) (Leuw 1991). Same-sex partners may marry and adopt children. Prostitution is legalized. So is euthanasia under certain circumstances. Private possession of firearms is prohibited.

The Netherlands is a constitutional monarchy and a parliamentary democracy. The queen, aside from symbolic constitutional functions, plays mainly a ceremonial role. The lower house (Tweede Kamer), which plays the central role, has 150 seats, and the upper (Eerste Kamer) has 75.

The Netherlands has long been ruled by coalition governments. Starting in 1994, a coalition of Christian-democratic, liberal-conservative, and liberal-democratic parties made up the governing coalition. Following an election in 2002 held shortly after the murder of the flamboyant populist and anti-immigrant politician Pim Fortuyn, the Dutch government moved distinctly to the right. A coalition of religious, conservative and liberal democratic parties took office, and policy on a number of high-visibility subjects-support for the U.S.-led war in Iraq, treatment of immigrants, criminal justice-shifted. The subsequent murder of filmmaker and provocateur Theo van Gogh, who made a practice of insulting unassimilated Muslims, produced still harsher attitudes toward immigrants and heightened doubts about the wisdom and effects of Holland's traditional multicultural approach toward assimilation.

Demographic characteristics resemble those of other affluent Eu- 
ropean countries. The population is aging fast. Life expectancy in 2001 was 75.8 for males and 80.7 for females. About one in three marriages ends in divorce. About one in four children is born out of wedlock, and one in six lives in a single-parent household. All children aged five to fifteen receive full-time education. About 22 percent of the population between fifteen and sixty-four is in or has received higher education; this figure has been increasing in recent years. The unemployment rate is low, as is inflation. Most households have one or more cars. There are more bicycles than people. Many people use them (or mopeds) for transportation since the country is flat, towns are congested, and distances are short.

The Netherlands is an advanced social welfare state: those without jobs are entitled to income and other support. Levels of financial support have recently decreased, and eligibility rules have tightened, but no legal resident in the Netherlands need go hungry or without a place to live. Families with children receive child benefits. Medical care for legal residents is provided under state-supervised insurance schemes, and health insurance subsidies are provided to people with incomes below designated levels.

The relaxed and tolerant atmosphere of earlier times has changed in recent years. Pim Fortuyn was murdered by an animal rights activist and Theo van Gogh by a jihadist of Moroccan origin. Antiterrorism laws have been enacted. Closed-circuit television is in operation in many places. The Somali-born liberal-conservative parliamentarian Ayaan Hirsi Ali and the extreme right-wing politician Geert Wilders have been threatened because of their radical views (Buruma 2006).

\section{The People}

The Netherlands is rapidly becoming a multiethnic, multicultural country. Only 9.2 percent of the population in 1972 were of nonethnic Dutch origin; 1.2 percent were of non-Western origin. By 2006, people who were foreign-born or had at least one foreign-born parent made up 19.3 percent of the population; more than half, 10.5 percent, were of non-Western origin. Citizens of Dutch ethnic or other Western descent are generally wealthier, better educated, better employed, healthier, and less involved in violent and property crimes than non-Western minority residents (particularly younger ones). 
There are big differences, however, between and within minority ethnic groups.

Large cities have concentrations of lower-income minorities and indigenous Dutch, but there are no residential areas equivalent to the urban ghettos of the United States or the banlieus of Paris. Dutch people generally dislike racial and ethnic categories and labels, perhaps because of the persecution of Dutch Jews by German occupiers during World War II: 70 percent of Jewish inhabitants were deported and killed, including 90 percent of those in Amsterdam. Perhaps for this reason, records of individuals' racial characteristics are not maintained. In official statistics, residents are identified as non-ethnic Dutch when at least one parent was born outside the Netherlands.

The composition of the Dutch population has never before changed as rapidly as in the past four decades. After the relatively easy integration of people from the former Dutch East Indies after Indonesia became independent in 1949, retroactively formalized as from 1945, labor migrants mainly from Turkey and Morocco made up the next big wave of immigrants. Their stays were initially envisioned as temporary, but most settled. Their families came later, and their descendants make up a growing part of the population.

Almost all Turkish and Moroccan migrants are Muslims. Turkish migrants came mainly from rural areas in central and eastern Turkey. Many are ethnic Kurds. The Moroccans mainly came from the poor rural area called the Rif. Most are Berbers, not ethnic Arabs, and speak Tamazight, a Berber language, as a first language and Arabic as a second.

Postindependence migrants from the former colony of Dutch Guyana (now Surinam) came to the Netherlands in large numbers around 1975, just before Surinam became independent. Its inhabitants were given the choice to remain in Surinam or to settle in the Netherlands. Most Surinamese speak Dutch. Their ethnic makeup is diverse and includes descendants of people brought as laborers to Surinam from the Indian subcontinent, Africa, Java, and China.

The Netherlands Antilles remain part of the kingdom of the Netherlands. Travel is not unrestricted, but many (mostly young male) Antilleans have settled in the Netherlands, more or less permanently. They often do not speak Dutch, but Papiamento.

More recent migrant groups, mostly asylum seekers (prominently from Iraq, China, Iran, Afghanistan, and Somalia), have augmented the 
nonindigenous population. Many who obtain a residence permit subsequently seek and obtain approval for migration by relatives for family reunification or formation.

Many nonindigenous Dutch migrants, particularly from the former Dutch East Indies, have successfully integrated, but this is less true for many of the more recent migrants. Many non-Western immigrants live in the big towns (about a third each of the populations of Amsterdam and Rotterdam in 2002 were of non-Western descent). A sizable fraction occupies the country's lower socioeconomic strata. Those with refugee status and families of Moroccan origin are especially likely to be found there.

The employment rate for non-Western migrants is worse than for indigenous Dutch: 73 percent of indigenous Dutch were employed in 2003, compared with 56 percent of nonindigenous Dutch and 51 percent of non-Western residents. The data for unemployment benefits are similar: 13 percent of indigenous Dutch are in some kind of unemployment scheme compared with 16 percent of Western migrants and 25 percent of non-Western migrants. Among asylum migrants the unemployment rate was $23-40$ percent for males and 38-70 percent for females (Bijl et al. 2005). Children from ethnic minority families finish school less often and with lower degrees than children from ethnically Dutch families, and the gap is not decreasing significantly; girls overall do better than boys (Bijl et al. 2005).

Members of some ethnic minority groups are overrepresented in Dutch crime statistics. Of all registered suspects in 2002, 62.5 percent were ethnically Dutch and 37.5 percent were from other groups. Overall, 1.6 percent of male ethnic Dutch residents were identified in police data systems as a suspect; among non-ethnic Dutch males, 4.2 percent were. Among ethnic Dutch and other females, the corresponding figures are 0.3 percent and 0.8 percent (Blom et al. 2005). The overrepresentation is higher for juveniles: first-generation Antillean and Moroccan juveniles' representation in police statistics is three times that of Dutch juveniles, according to Blom et al. In Dutch prisons, 74 percent of detainees have Dutch nationality; however, 50 percent were born outside the Netherlands (Dienst Justitiële Inrichtingen [DJ]: http://www.dji.nl/ $/$ main.asp?pid $=40 \&$ sectorid $=2 \&$ catid $=3,2005$ ). 


\section{The Criminal Justice System ${ }^{2}$}

Dutch police, prosecutors, and judges have wide discretionary powers. During the closing decades of the twentieth century, the powers of the police and the prosecution grew substantially. Their authority to dispose of cases without referring them to the courts expanded substantially. The judiciary has wide discretionary powers in sentencing. Legislation establishes maximum sentences for particular crimes, and there are no minimums.

\section{A. Police}

The police are divided into twenty-five regional forces. Each falls under the administrative authority of the mayor of the largest city in the region. The public prosecutor, however, is responsible for overseeing police investigations. A small national force handles specific tasks (e.g., motorway policing, central criminal investigations, international contacts, international and war crimes). There is also a military police force with several "civil" tasks, most notably border control and Amsterdam's Schiphol Airport. Special agencies handle regulatory offenses such as tax and social security fraud.

Suspects are processed first through the police system. When the police decide that a suspect has committed a crime, the case in principle should be transferred to the public prosecutor. In some cases, especially for juveniles who have committed minor offenses, the police may send the suspect home with a warning or a small fine and no prosecution ensues. Since 1987, the police have had authority to handle less serious offenses committed by juveniles by means of a HALT disposition, which is usually a kind of community service. For driving offenses, shoplifting, and other lesser property crimes, police can dispose of cases on the condition that the suspect pays a fine; this is in effect a lower-level version of the prosecutorial transactions described in the next subsection. In other situations, the case is referred to the public prosecutor's office.

\section{B. Prosecution}

The prosecutor's role is central. The prosecution is responsible for overseeing the investigation and decides whether to prosecute or to drop the case. The prosecution is authorized to deal with less serious

${ }^{2}$ Junger-Tas (2004) and Tak $(2001,2003)$ respectively provide comprehensive overviews of the Dutch juvenile and (adult) criminal justice systems. 
cases without referring them to the courts by means of "transactions" (agreements that the suspect will accept a penalty that might have been imposed had the case gone to trial) or other conditions for dismissal of the case. The offender can refuse the offer (if so, the case will go to court). One advantage for the offender is that agreement to a transaction will not result in a criminal record that will show up in a background check. Only a judge has authority to find a suspect guilty. This means that there is no institutionalized "plea bargain," although the transaction resembles one functionally.

Public prosecutors in the Netherlands, though appointed directly by the minister of justice and the Crown, fall under a central office (the Board of Procurators General, the Parket-Generaal) led by three to five chief prosecutors. Prosecutors, unlike judges, are not appointed for life.

\section{Courts}

Judges are appointed for life by the minister of justice and the Crown. Juries are not involved in the trial of cases, and lay judges are almost absent. This is different from most surrounding countries, where juries or lay judges without specialized academic training, or both, play important roles trying cases and deciding punishments.

The courts of first instance consist of one judge (politierechter) for less severe offenses (with authority to impose custodial sentences up to six months) or three judges for the more serious cases (meervoudige kamer). Appellate courts generally consist of three judges.

Most investigation is done by the police in the pretrial stage. Findings are reported in the case file. Most of the time, no interrogation of witnesses and experts takes place at the trial. Judges base their decisions primarily on interrogations of suspects and written dossiers (Malsch and Nijboer 1999). Interpreters are provided during trials and interrogation to defendants who do not speak Dutch.

The media have access to criminal trials, but use of cameras is limited. Media coverage is generally limited to imposition of the sentence or the start of a prosecution. Compared with media in other countries, the Dutch media are relatively restrained in reporting about criminal trials.

\section{Punishment}

Sanctions range from fines and community service to treatment measures (leerstraf) to imprisonment. All can be imposed conditionally as 
well as unconditionally. Sanctions can be punishments, which must be proportionate to the offense, or measures (such as treatment), which serve a more rehabilitative goal and need not be proportionate.

Especially for violent and sexual crimes, entrustment orders (terbeschikkingstelling, commonly called TBS) may be given, often in combination with a prison sentence. An entrustment order can be imposed for crimes carrying a statutory maximum sentence of four years or more imprisonment, if the offender cannot be held fully responsible for his or her behavior, and if hospital care is deemed necessary to protect other people, the general public, or property. The order lasts two years but may be extended. The average time spent on an entrustment order is more than six years. Some on whom treatment is imposed may spend the rest of their lives in confinement if treatment is unsuccessful and their chances of recidivism remain high (Leuw 1999).

Determinate custodial sentences vary between one day and twenty years. Life sentences are seldom imposed (though their use has increased in recent years). Sentence length depends on the severity of the offense, whether the offender is a recidivist, and other case-specific circumstances. Prisoners are entitled to release after serving a specified percentage of their sentences. There is no system of discretionary parole release.

All prisons are operated by the state. They are small, the largest having a capacity of fewer than 400 cells. The total regular capacity for adults (nonjuveniles, non-TBS) by the end of 2005 was 15,601 cells (DJI 2007). Besides adult institutions, there are institutions for young offenders, psychiatric institutions for offenders, and places for detained illegal aliens who are subjects of civil administrative law proceedings. Three-quarters of prisoners are in short-stay facilities that house pretrial detainees and persons serving short terms.

An inmate's quality of life in a Dutch prison is high, compared with prisons elsewhere, at least in a material sense. Detainees can have a television and video in their cell (at their own expense), and sports activities are available. Prisoners serving long sentences may be granted unsupervised visits.

In other respects, the regimes are strict and have recently become stricter. Sentenced prisoners can be required to participate in prison labor. Contacts with the outside world are strictly regulated. Because of the rapid growth of the prison population, sharing of cells has been allowed since 2003. 


\section{Crime and Punishment Trends ${ }^{3}$}

Among European countries, the Netherlands stands out in the growth over three decades of its imprisonment rate and its prison capacity and population. Otherwise-in crime and victimization rates and trends, changes in sanctioning policies and practices, and evolution of systems of official data-it is in the mainstream. There is, however, some confusion about imprisonment rates, and for some offenses there is some uncertainty about crime rate trends.

\section{A. Imprisonment Rates}

The broad patterns are clear. The imprisonment rate grew steeply and continuously for three decades from being the lowest in western Europe to being one of the highest. In contrast to the United States and England, other countries that experienced steeply rising imprisonment rates over extended periods through 2006, the increase occurred without enactment of dramatically harsher sentencing laws and without crime control becoming a preoccupying partisan political issue.

Figure 1 shows the imprisonment rate per 100,000 population aged fifteen to sixty-five for the period 1960-2005, including remand and sentenced adult prisoners, juveniles detained under a criminal law order, and TBS detainees. Represented in this way, the rate approximately halved between 1960 and the early 1970s and then quadrupled, approaching 160 per 100,000 in 2005. Calculating imprisonment rates this way adjusts demographically for the size of the population realistically at risk of being in prison, but it is not generally the basis for international comparisons.

International comparisons generally use imprisonment rates per 100,000 national population, but this can be misleading depending on what subpopulations are included (e.g., adults only or including juveniles, whether illegal aliens, whether residents of psychiatric institutions for offenders). Figure 2 shows the Dutch imprisonment rate per 100,000 general population and calculated to include the same categories of confined persons as in figure 1 .

Dutch imprisonment rates are sometimes said to have increased sixfold since 1973-74, but that is wrong and appears to result from comparing recent rates based on the population aged fifteen to sixty-five

\footnotetext{
${ }^{3}$ Bijleveld and Smit $(2004,2005)$ provide detailed analyses of crime and punishment trends in 1980-99.
} 


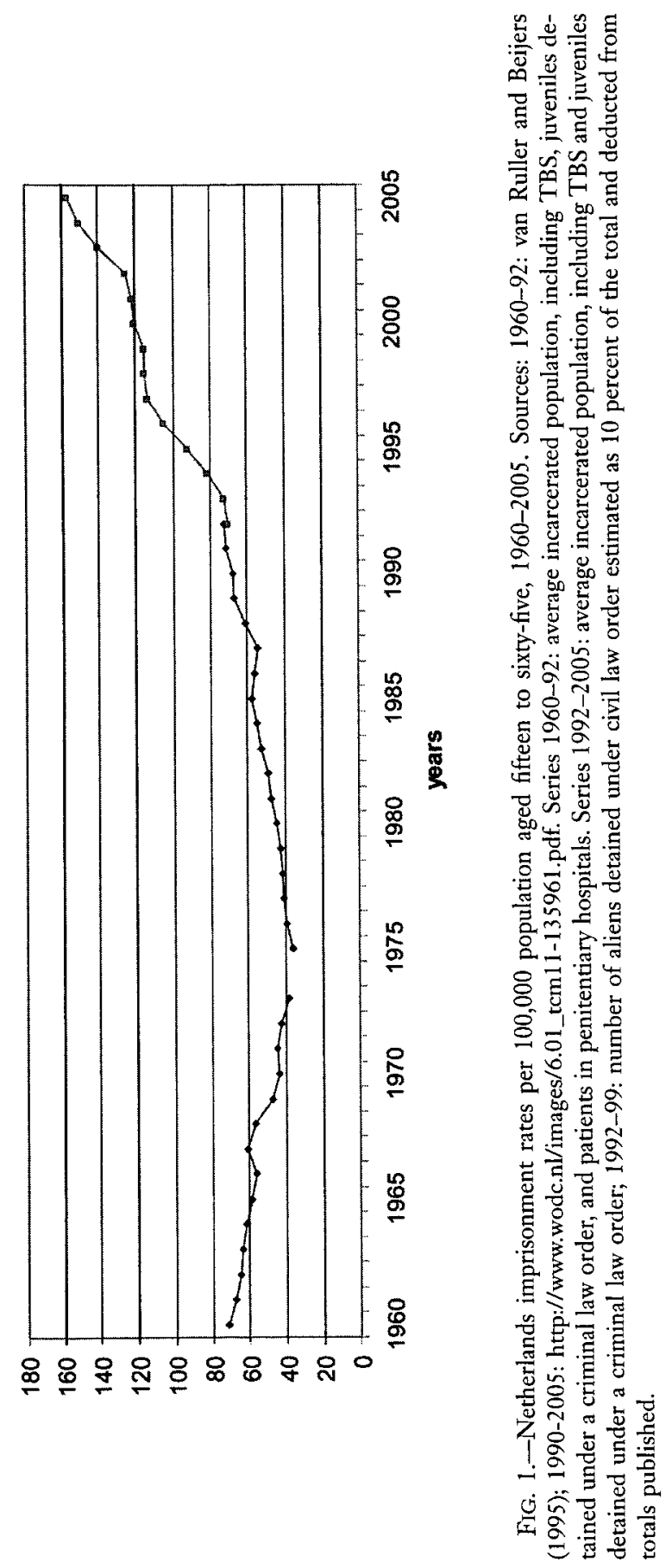




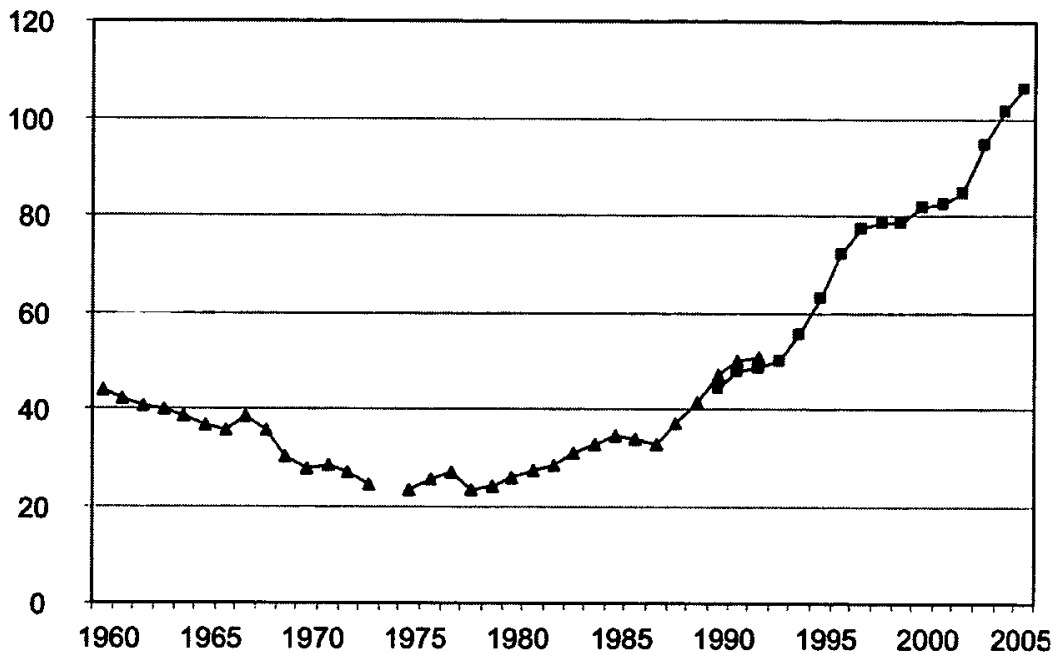

FIG. 2.-Netherlands imprisonment rates per 100,000 population, 1960-2005. Sources: 1960-92: van Ruller and Beijers (1995); 1990-2005: http://www.wodc.nl/images/ 6.01_tcm1 1-135961.pdf. Series 1960-92: average incarcerated population, including TBS, juveniles detained under a criminal law order, and patients in penitentiary hospitals. Series 1992-2005: average incarcerated population, including TBS and juveniles detained under a criminal law order; 1992-99: number of aliens detained under civil law order estimated as 10 percent of the total and deducted from totals published.

(150-160 per 100,000) with the 1973-74 rate based on the total population (mid-20s per 100,000).

Notwithstanding those qualifications, however, and whichever method is used to calculate rates, Dutch use of imprisonment has increased substantially and rapidly by European standards. Table 1, based on Council of Europe data, shows imprisonment rates for selected European countries in 2004. ${ }^{4}$ Among ten E.U. countries (out of fifteen) for which data were available and Switzerland, only England and Wales and Spain had higher imprisonment rates than the Netherlands; the Dutch rates were nearly double those in Scandinavia and a third higher than in France, Germany, and Italy.

Table 2 shows imprisonment rates from the Council of Europe for

${ }^{4}$ The data shown in tables 1 and 2 are as reported to the Council of Europe by national governments. The Dutch data, consistent over time, include categories of confined persons (e.g., young persons confined under civil law orders) not included in our figs. 1 and 2. 


\section{TABLE 1}

Imprisonment Rates, Selected European Countries, September 1, 2004

\begin{tabular}{lccc}
\hline Country & $\begin{array}{c}\text { Population } \\
(2004)\end{array}$ & $\begin{array}{c}\text { Number of } \\
\text { Prisoners } \\
(2004)\end{array}$ & $\begin{array}{c}\text { Per 100,000 } \\
(9 / 1 / 2004)\end{array}$ \\
\hline Denmark & $5,397,600$ & 3,762 & 69.7 \\
England and Wales & $53,046,300$ & 74,488 & 140.4 \\
Finland & $5,219,700$ & 3,446 & 66 \\
France & $62,177,000$ & 56,271 & 90.5 \\
Germany & $82,531,700$ & 79,676 & 96.5 \\
Italy & $57,888,200$ & 56,090 & 96.9 \\
Netherlands & $16,258,000$ & 20,075 & 123.5 \\
Norway & $4,577,500$ & 2,975 & 65 \\
Spain & $42,197,900$ & 59,224 & 140.3 \\
Sweden & $8,975,700$ & 7,332 & 81.7 \\
Switzerland & $7,364,100$ & 6,021 & 81.8 \\
\hline
\end{tabular}

SOURCE.-Council of Europe (2005), table 1.

the same eleven countries in 1977, 1990, 1999, and 2004 and percentage changes from each prior year through 2004. In each period the cumulative Dutch increase is substantially higher than any other. Over the entire twenty-seven years the Dutch imprisonment rate grew 375 percent. Spain was next highest at 119 percent.

An interesting question is why imprisonment rates rose so rapidly and for so long, especially in the absence of dramatic policy changessuch as three-strikes and mandatory minimum sentence laws in England and the United States-meant to increase prison use dramatically. Crime rates increased substantially in the 1970s, 1980s, and $1990 \mathrm{~s}$, and it is not unreasonable to suppose that led to increased imprisonment. In practice, however, comparative research shows that there is no necessary relation between crime and imprisonment rates (Tonry 2007). Parts of the explanation for the Dutch pattern are known. A first, and the most mechanical, is that periodic expansions in prison capacity have to some extent driven the size of the prison population. Until 2003, the Netherlands observed a policy of one prisoner to a cell. When space was unavailable, both remand and sentenced prisoners were placed on waiting lists for admission; when the wait became too long, many were spared prison altogether. In 1995, remand prisoners were sent home on more than 5,000 occasions because of a lack of space (Verhagen 2005, fig. 39). 
TABLE 2

Imprisonment Rates per 100,000 Population, Selected Countries, $1977,1990,1999$, and 2004

\begin{tabular}{|c|c|c|c|c|c|c|c|}
\hline Country & 1977 & 1990 & 1999 & 2004 & $\begin{array}{c}\text { Change } \\
1999-2004 \\
(\%)\end{array}$ & $\begin{array}{c}\text { Change } \\
1990-2004 \\
(\%)\end{array}$ & $\begin{array}{c}\text { Change } \\
1977-2004 \\
(\%)\end{array}$ \\
\hline Denmark & 62 & 65 & 67 & 69.7 & 4.0 & 7.2 & 12.4 \\
\hline England and Wales & 81 & 93 & 122 & 140.4 & 15.1 & 51 & 73.3 \\
\hline Finland & 115 & 65 & 50.5 & 66 & 30.7 & -1.5 & -42.3 \\
\hline France & 62 & 82 & 88.5 & 90.5 & 2.23 & 10.34 & 46 \\
\hline Germany & $83 *$ & $78^{*}$ & 98.3 & 96.5 & -1.8 & 23.7 & 16.3 \\
\hline Italy & 56 & 57 & 9.3 & 96.9 & 8.5 & 70 & 73 \\
\hline Netherlands & 27 & 44 & 84 & 123.5 & 47 & 180.68 & 357.41 \\
\hline Norway & 49 & 57 & 58.5 & 65 & 11.1 & 14 & 32.65 \\
\hline Spain & 64 & $\mathrm{NA}$ & 114 & 140.3 & 23.1 & $\mathrm{NA}$ & 119.2 \\
\hline Sweden & 51 & 58 & 61.9 & 81.7 & 32 & 40.9 & 60.2 \\
\hline Switzerland & 55 & NA & 88.5 & 81.8 & -7.6 & NA & 48.7 \\
\hline
\end{tabular}

SOURCE.-2004: Council of Europe (2005), table 1; 1999: Council of Europe (2001), table 1; 1990: Council of Europe (1992), table 1; 1977: Kaiser (1984), p. 184.

${ }^{*}$ West Germany only.

In the 1970 s, after a round of prison closings, capacity was very low, and exceptionally low rates in the mid-twenties were the result. The comparatively level imprisonment rates shown in figures 1 and 2 in the 1990s occurred at a period of insufficient capacity, and the subsequent rise coincides with a substantial expansion in capacity. The expansion after 2003 results in part from abrogation of the one-prisoner, one-cell policy.

A second explanation is a general turn toward greater severity that manifested itself throughout the justice system. More suspects were held in pretrial detention, and the fraction of pretrial detainees in the total prison population significantly increased. The actors and agencies that make up the criminal justice system over time sent increasingly larger percentages of convicted offenders to prison and (for many offenses) for longer times. Between 1985 and 1995, the percentages of registered crimes resulting in unsuspended prison sentences increased substantially for violent (16-21 percent), drug (22-34 percent), and property crimes (13-18 percent) (Tak 2001, table 4.9). The average prison sentence increased from 59 days in 1970 to 96 in 1980, 152 in 1990, and 197 in 1995 (table 4.11). Between 1980 and 1999, both conviction and imprisonment probabilities increased for assaulters and robbers, as did the odds of receiving a prison sentence and average 
days of imprisonment if convicted (Bijleveld and Smit 2004, tables 4-6).

Data on increasing prison capacity and severer punishment practices give some indication of what is happening, but not why. A growing comparative and cross-national literature explores determinants of changing penal policies, focusing on such things as changing crime rates, public attitudes and anxieties, and criminal justice policies; deeper changes in social and economic conditions; and evolving cultural norms and sensibilities (Boutellier [2005] has written of these changes in the Dutch context).

The history of penal policy in the Netherlands remains to be written, and perforce it will explore such subjects. It is clear that something fundamental has changed (Downes and van Swaaningen, in this volume). Van Ruller and Beijers (1995) analyzed Dutch incarceration data, broadly defined to include adult prisons, juvenile facilities, and mental institutions, from 1837 to 1992 . Their data suggest that something dramatic happened in the 1970s (see fig. 3). We have added comparable data through 2005. Aggregate imprisonment rates fell steeply and almost continuously from 1837 to 1975 and then changed direction. The increase since then has not been continuous but would have been had imprisonment rates not been distorted by changes in capacity, waiting lists, and the one-prisoner, one-cell rule.

Van Ruller and Beijers describe a number of factors that may have influenced the post-1975 rise. One is the combination of limited capacity, the one to a cell policy, and waiting lists. A second is an increase in the number of serious offenses. A third is harsher sentencing practices. A fourth is more vigorous enforcement of hard-drug laws. A fifth is a combination of the Netherlands' role as a transit hub combined with open borders and easy international mobility, which necessitates locking up suspects for fear that they may otherwise leave the country. A sixth and seventh are two "psychological" considerations: that judges have perceived the Dutch mild penal climate to be out of synch with those of surrounding countries, and that the climate had changed from one of compassion for the perpetrator to one of compassion for the victim, resulting in harsher attitudes toward crime and criminals.

\section{B. Crime Rates}

Rates of recorded crime broadly rose in most Western countries during the 1970s and 1980s, reaching peaks at some point in the early 


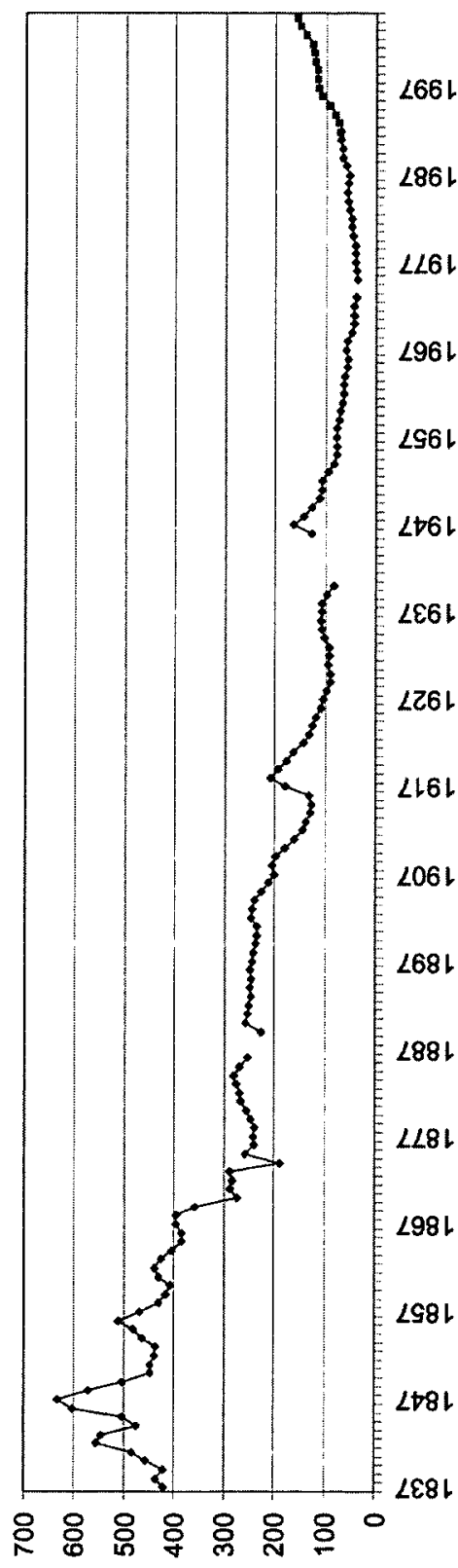

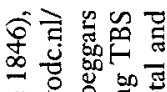

을

绨

类

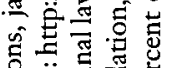

莒是

훙혀 응

范

원

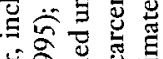

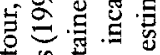

1)

次:

8 表市

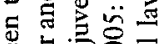

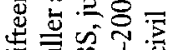

类 1

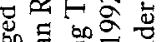

of

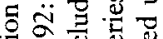

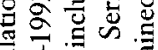

言领

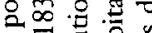

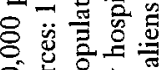

\&

饱苞

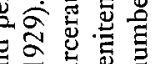

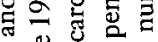

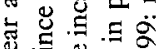

递

记

.

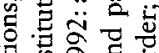

负综

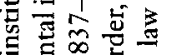

a

동

的

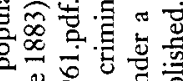

设实

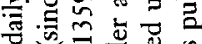

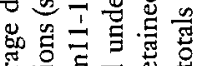

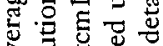

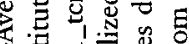

1 象家

m.

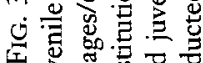

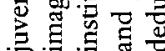


to mid-1990s and declining or stabilizing thereafter. Changes in reporting and recording took place in all countries during that period, and some countries changed their criminal codes to redefine offenses in ways that make comparison of crime rates over time even more difficult. Homicide, because of its seriousness and the possibility of validating police data with health system data, and automobile theft, because insurers typically will not cover a claim unless the loss was reported to the police, are generally believed to be the most accurate official crime data. Assaults and sexual offenses are generally believed to be the offenses least accurately measured by official data because there have been substantial and repeated changes in social attitudes and official policies toward both in recent decades that conduce to higher recording and reporting rates. In general, people have become less tolerant of violence and unwanted sexual contacts and more likely to report them to the police. The police in turn have become more likely to record them as crimes.

Identifying trends in the incidence of serious crimes in the Netherlands is more difficult than in some other countries because of the nature of some definitions of offenses in Dutch criminal law. For some of the offenses about which citizens are most concerned, the existing definitions make trend statistics difficult to compile or interpret. There is, for example, no separate article for burglaries; they make up about a fifth of the entries under article 311 ("qualified theft"). There is likewise no separate offense of motor vehicle thefts; they are classified sometimes as general theft (art. 310), sometimes under 311, and sometimes under other articles. Dutch victimization surveys and the International Crime Victimization Survey (ICVS) in which the Netherlands participates have working definitions for some of these offenses, but those definitions have changed over time and are difficult to relate to the criminal code definitions (Bijleveld and Smit 2004, p. 164).

It is likely that crime trends in the Netherlands in recent decades followed those in other Western countries, but that is less clear from official records than is true elsewhere. Figure 4 shows police data on recorded aggregate property and violent crime rates per 100,000 population aged twelve to seventy-nine years for the years 1960-2004. The property crime rate rose steadily from 1960 to 1985 , reaching a plateau that lasted through the early 1990s, followed by a sizable fall, an increase to a point lower than the prior peak, and another fall. The violent crime rate increased throughout the entire period. 


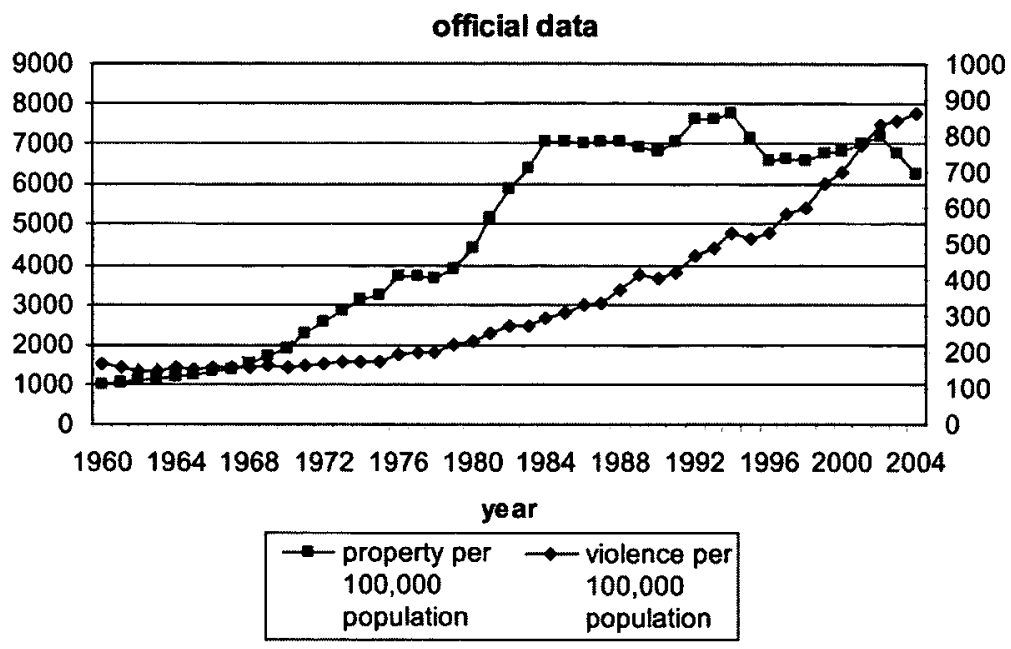

FIG. 4.-Property and violent crime rates per 100,000 population aged twelve to seventy-nine years, Netherlands, 1960-2004. Sources: CBS Statline, WODC (http:// www.wodc.nl/Cijfers/CriminaliteitenRechtshandhaving/), tables 4.2, 4.3.

It is difficult to know how much of the apparent increases, especially for violence, is real and how much is the artifactual effect of reporting and recording changes. Much of the increase in violence rates is almost certainly the product of changes in police recording practices. During the period 1980-99, the probability that an assault was reported to the police increased slightly, but the probability that the reported incident was recorded as an assault by the police increased threefold (from 19.4 percent in 1980 to 58.1 percent in 1999). For robbery the recording increase is less (from 5.8 percent in 1980 to 14 percent in 1999) (Bijleveld and Smit 2004, tables A3, A4), but still a 150 percent increase. Assaults and threats are the most frequent violent crimes, and their numbers drive the total violent crime rate. Trends in recorded violent crime accordingly probably overstate the increase in violence.

The story for property crimes is much the same. Although levels of citizen reporting of burglary and motor vehicle theft did not change much between 1980 and 1999, police recording practices did. For burglary, the probability of police recording of reported offenses nearly doubled from 22.3 percent in 1980 to 42.1 percent in 1999. For motor vehicle theft, the recording rate rose from 23.9 percent of reported 


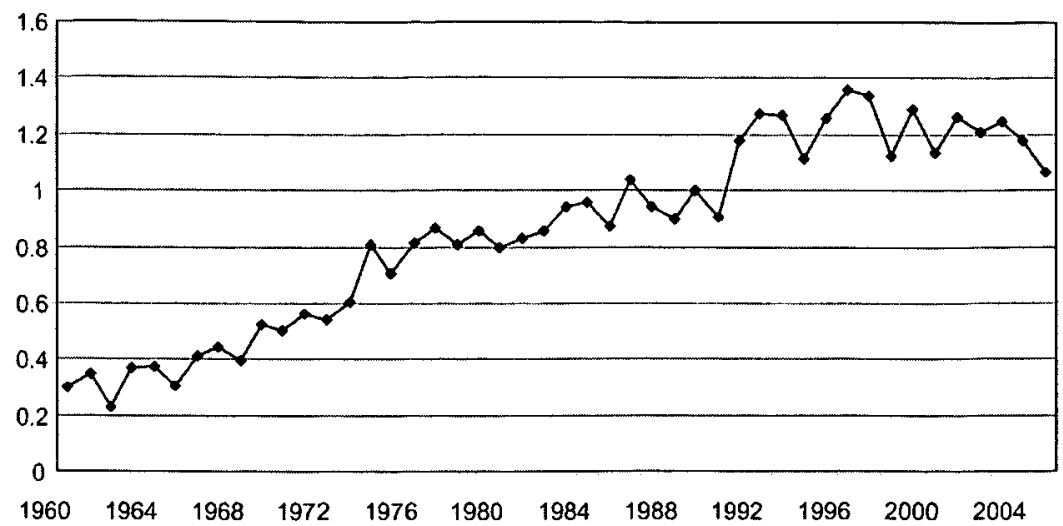

FIG. 5.-Homicides per 100,000 inhabitants, 1960-2004. Source: Nieuwbeerta and Deerenberg (2005).

offenses to 58.1 percent (Bijleveld and Smit 2004, figs. 2a, 2b). Although theft is the most numerous of property crimes, burglary and motor vehicle thefts also are common. The substantial increases in recording rates for those offenses, especially in the 1990s, when property crime rates were falling, suggest that the falls were real.

In principle, homicide should provide a leading indicator of violence trends, assuming that the number of homicides is probabilistically related to the number of violent incidents. Reasons why this assumption might be incorrect include changes in the circumstances in which deaths occur (e.g., an increase in the fraction of homicides occurring in organized crime contexts, changes in weapon lethality such as shifts from knives to guns or from lower- to higher-caliber guns) and changes in the effectiveness of medical responses to violence.

Homicide is less likely than other crimes to be susceptible to large changes in reporting and recording. If homicide is viewed as the tip of the iceberg of violent offending, research on homicide levels suggests that violence increased from 1960 through the early 1990s, after which it stabilized and most recently may have begun to decline. This can be seen in figure 5 , which shows homicide rates per 100,000 population from 1960 to 2004. From 1965 to 1990, yearly homicide rates increased nearly threefold, to 1.2 per 100,000 , and have remained fairly stablesince, hovering around a little over 200 per year. Nieuwbeerta and 
Deerenberg (2005) show that the rise took place mainly in the three largest cities (Rotterdam, Amsterdam, and The Hague) and among young and adult males. Firearms were involved in an increasing fraction of deaths over this period.

The homicide data thus show a marked rise since 1960, although not as strong as the rise in police-recorded violent offenses. Plausible hypotheses, however, can be offered that part of the rise is explained by the increasing prevalence of firearms (an assault with a gun is more likely to result in death than are other assaults) and that part is explained by an increasing proportion of homicides related to otherwise criminal activities.

Whatever the reasons for the rise, the levels reached in the 1990s and sustained since then are typical of western European countries. Most have homicide rates between 1.0 and 1.5 per 100,000 population (Aebi et al. 2006, tables 1.2.1.4, 1.1.2.5).

From official records, then, it appears that both property and violent crime increased in the 1970s and 1980s, though considerably less than official data suggest, and that property crime rates began to fall in the 1990 s. It is more difficult to generalize about recent violence trends. However, under the assumption that homicide is a leading indicator of violence generally, the stabilization of homicide rates in the early $1990 \mathrm{~s}$ and the subsequent slight decline suggest that the true incidence of violence in society has not been increasing for more than a decade. Wittebrood and Nieuwbeerta (2006), using victimization data, showed for the period 1980-2004 for a number of smaller categories of offenses that most of the rise in recorded crime could be explained by increased reporting and recording, and only a small proportion by rising crime levels as such.

\section{Victimization Surveys}

Data generated by victim surveys, the other source of data on crime over time, agree with the official data on property crime but disagree about violence (in contrast to the police data, also showing a decline). Figure 6 provides aggregate data on victimization rates per 100,000 for violent and property crimes from 1980 through 2006. Reported victimization levels are fairly stable, decreasing from 16,000 to 14,000 incidents per 100,000 population per year. It shows that reported victimization by property crime declined in the late 1990s. For violent crime, 


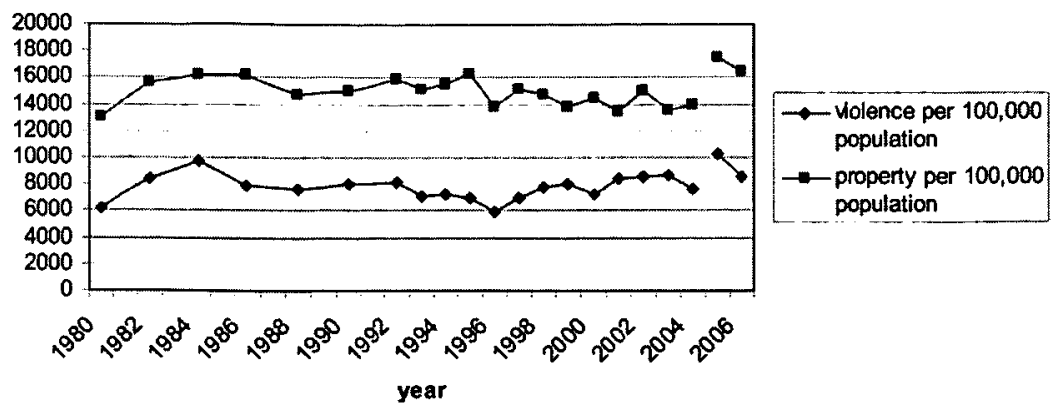

FIG. 6.-Victimization violent and property offenses, Netherlands, 1980-2006. Source: WODC and CBS victim surveys.

it indicates a drop in the mid-1980s followed by another drop in the mid-1990s to a stable lower level.

Most writers in the Netherlands contend that the victim surveys give better information and that the rising crime levels indicated by the official data reflect increased administrative efficiency and, for violent offending, increased labeling of behavior by victims and officials. There clearly have been changes in reporting behavior and recording practices. The overriding difficulty is not knowing how much those changes have affected apparent crime levels and trends

While an argument can be made that victimization data are more reliable indicators of trends because they are not distorted by officials' recording decisions and because often they are based on large samples, other considerations make them less persuasive. They do not measure one of the most serious crimes, homicide, and do not report data for another, rape (the former for obvious reasons and the latter because rape is too rare an event to obtain credible estimates from victim surveys); what they do measure is heavily biased toward less serious crimes. There are also questions about their representativeness; response rates for Dutch national victimization surveys hover around 50 percent and have gone down steadily over the years. Since the hardestto-locate respondents (poor, mobile, living socially disorganized lives) are the likeliest to be high-rate offenders and victims, nonrepresentativeness is a nontrivial problem. Figure 6 is derived from data from several_surveys: the WODC victim survey (1973-80), three different subsequent Statistics Netherlands victim surveys (1981-2004), and the 
latest VeiligsheidsMonitor Rijk victim survey (2005 and 2006). The last was not synchronized with its predecessors.

However, the ICVS does confirm that victimization in the Netherlands has declined since 1989, when that survey was first administered. Table 3 shows levels of reported victimization per 100,000 residents for burglary, thefts of and from cars, and theft of personal property (the sample sizes are too small to generate useful estimates about violent crimes) for eight western European countries for the years 1988, 1991, 1995, and 1999, including many of those whose imprisonment rates are included in tables 1 and 2. The two patterns that stand out for the Netherlands are that reported victimization rates are in the mainstream and, as in almost every other European country, peaked in the 1990s and have since fallen. These two patterns are confirmed by findings from the latest wave of ICVS data collection in 2004 (van Dijk 2006; van Dijk et al. 2007, chap. 2). Aggregate victimization rates in every western European country participating in the 2004 wave had fallen substantially from high points in the 1990s.

This brief overview of crime, victimization, and punishment trends in the Netherlands shows several things: Dutch imprisonment rates have risen much faster and more steeply than those in other European countries, and Dutch rates are now at or near the top in Europe; official and victimization data indicate that property crime rates have fallen and violent crime rates have stabilized.

\section{Implications for Research}

The Netherlands has a rich tradition in criminology and criminal justice research, and thriving (and rapidly growing) research and teaching communities (van Swaaningen 2006; Junger-Tas and Junger, in this volume). Its crime control and punishment policies have consistently attracted attention from outsiders because of the liberality of its longstanding policies on drugs and prostitution and because of its gradual, long-term shift away from having one of the most restrained punishment systems in Europe.

Dutch research is reasonably ample and impressively vibrant in a number of subjects, notably including organizational and white-collar crime (e.g., van de Bunt and Huisman, in this volume), organized crime (Kleemans, in this volume), juvenile delinquency (Weerman, in this volume), juvenile justice (Junger-Tas 2004), and immigration and crime 
TABLE 3

Victimization per 100,000 Inhabitants, 1988, 1991, 1995, and 1999: Selected Offenses and Countries

\begin{tabular}{|c|c|c|c|c|}
\hline Country & 1988 & 1991 & 1995 & 1999 \\
\hline & \multicolumn{4}{|c|}{ Burglary } \\
\hline Belgium & 2,800 & 2,600 & $\ldots$ & 2,400 \\
\hline England & 2,200 & 3,200 & 3,400 & 3,400 \\
\hline Finland & 600 & 600 & 800 & 500 \\
\hline France & 3,300 & $\ldots$ & 2,900 & 1,000 \\
\hline Mean & 2,800 & 2,800 & 2,500 & 2,300 \\
\hline Netherlands & 2,600 & 2,400 & 3,300 & 2,300 \\
\hline Scotland & 2,300 & $\ldots$ & 1,600 & 1,500 \\
\hline Sweden & & 1,500 & 1,500 & 2,300 \\
\hline \multirow[t]{2}{*}{ Switzerland } & 1,100 & $\ldots$ & 1,600 & 1,200 \\
\hline & \multicolumn{4}{|c|}{ Car-Related Crime } \\
\hline Belgium & 1,650 & 1,590 & & 1,540 \\
\hline England & 2,220 & 3,640 & 3,690 & 3,010 \\
\hline Finland & 1,100 & 1,350 & 1,110 & 1,340 \\
\hline France & 2,060 & $\ldots$ & 2,640 & 2,180 \\
\hline Mean & 2,050 & 2,330 & 2,280 & 2,020 \\
\hline Netherlands & 2,340 & 2,860 & 2,540 & 2,350 \\
\hline Scotland & 2,520 & $\ldots$ & 3,120 & 2,640 \\
\hline Sweden & $\ldots$ & 1,390 & 1,690 & 1,960 \\
\hline \multirow[t]{2}{*}{ Switzerland } & 880 & $\cdots$ & 1,530 & 890 \\
\hline & \multicolumn{4}{|c|}{ Theft, Personal Property } \\
\hline Belgium & 4,300 & 4,000 & $\ldots$ & 4,800 \\
\hline England & 4,000 & 5,000 & 5,500 & 5,700 \\
\hline Finland & 5,000 & 3,900 & 3,600 & 3,900 \\
\hline France & 4,200 & $\ldots$ & 4,800 & 3,100 \\
\hline Mean & 4,900 & 6,100 & 5,800 & 5,500 \\
\hline Netherlands & 5,200 & 4,900 & 9,000 & 6,000 \\
\hline Scotland & 2,800 & $\cdots$ & 5,500 & 5,000 \\
\hline Sweden & $\ldots$ & 5,400 & 5,800 & 7,200 \\
\hline \multirow[t]{2}{*}{ Switzerland } & 5,700 & $\ldots$ & 6,800 & 5,400 \\
\hline & \multicolumn{4}{|c|}{ Contact Crimes } \\
\hline Belgium & 2,900 & 2,100 & $\ldots$ & 3,500 \\
\hline England & 2,100 & 4,100 & 5,900 & 8,900 \\
\hline Finland & 2,900 & 6,600 & 5,600 & 5,100 \\
\hline France & 2,200 & $\ldots$ & 4,100 & 4,000 \\
\hline Mean & 3,800 & 4,800 & 4,800 & 4,800 \\
\hline Netherlands & 4,400 & 3,800 & 3,500 & 4,000 \\
\hline Scotland & 2,800 & $\cdots$ & 4,500 & 6,300 \\
\hline Sweden & & 3,200 & 4,800 & 4,900 \\
\hline Switzerland & 1,800 & . & 3,600 & 3,300 \\
\hline
\end{tabular}

SoURCE.-Nieuwbeerta (2002), pp. 51-52. 
(Engbersen, van der Leun, and de Boom, in this volume). Work in these areas matches that anywhere else in the world in vigor, sophistication, and imagination.

On a second set of subjects, the literatures and research communities are not yet large but are promising and will justify sustained investment over time in strategic programs of research and in the career development of subject matter specialists. Examples include urbanization and crime (e.g., Bruinsma, in this volume), sex offenses and offenders (e.g., Bijleveld, in this volume), violent and serious offending (e.g., Loeber and Slot, in this volume), and crime and human development (e.g., Blokland and Nieuwbeerta 2006).

On some other subjects, however, notwithstanding the existence of important individual studies, the corpus of research is comparatively meager and the number of involved researchers is small. Examples include gender and crime, costs of crime, cost-benefit and effectiveness studies, and treatment effectiveness.

There are, however, two major general areas in which Dutch research is conspicuously underdeveloped. The first is the operation of the criminal justice system. There is an astonishing lack of investment in baseline empirical studies of the operations of the police, prosecutors, courts, prisons, and community penalty systems and in the effectiveness of policy changes and experiments. In a country that has been increasing its use of imprisonment steadily for thirty years, it is remarkable that little important research on the operation of prisons and the effects of imprisonment has been carried out in recent decades. It is similarly remarkable in a country in which the public prosecutor occupies a considerably more powerful and influential role than prosecutors in most other countries that prosecutors receive so little research scrutiny. Similar observations could be offered about Dutch police, judges, and community corrections. There have been individual publications of note (e.g., van Koppen 2003; van Koppen and Schalken 2004), but none of these literatures are large.

Prison research can be used to illustrate the current lack of research and (therefore) knowledge about critically important subjects. Despite the example of extensive literatures in the English-speaking countries and Scandinavia on life inside prisons, on inmate and staff subcultures, on how they have changed over time, and on how they relate to prison management and to prisoners' postrelease behavior, there is no modern Dutch research. Despite the example of large international literatures 
on how prisoners adapt to and cope with prison life and on the prison's effects on their mental and physical health, there is no modern research. There is not a rigorous evaluative literature on the effects of recent changes in prison regime (e.g., greater austerity, multiple celling, longer sentences) on prison management, prisoner well-being, or prisoners' postrelease behavior. Fundamental baseline facts are not known: for example, concerning the lifetime probability of imprisonment for men and women and for members of different ethnic groups. There are no cost-benefit or cost-effectiveness literatures on the use of imprisonment compared with other sanctions or compared with other social policies for dealing with crime (comparing, e.g., the cost-effectiveness of investments in prisons with investments in developmental and other forms of crime prevention). There is no published research on the collateral consequences of a prison sentence (or any other sanction) on prisoners' subsequent employment, earnings, physical and mental health, or family functioning or on the lives of prisoners' partners and children.

Similar paragraphs could be written about the police, prosecution, judicial, and community penalty systems. Greatly expanded programs of research on these subjects are important not only from rationalistic and humanitarian perspectives. Governments make better choices when their decisions are based on credible information. Precious little credible, research-based information is available on criminal justice system operations or on the effects of recent policy changes.

Historical studies of crime and justice system operations are a second area in need of reinvigoration. René van Swaaningen (2006) recently showed that historical scholarship on the subjects flowered in the $1990 \mathrm{~s}$ but has since gone into hibernation. Historical research, for which the Netherlands' well-kept archives make it especially well suited, should be revived. Important work was carried out earlier by Faber (1983), van Egmond (1993), and van Ruller and Beijers (1995), but little important work has recently been published. Exceptions are Pieter Spierenburg's ongoing research, Croes and Tammes' (2004) landmark study of the persecution of the Jews in World War II, and Fijnault's (2007) history of Dutch police. Van Ruller and Beijers in their statistical analyses showed that overall confinement rates fell steadily for a century and a half and in 1975 changed direction. Explaining why that happened is but one among many worthy missions for Dutch historians.

A specific modern historical subject that is starkly underresearched 
is the evolution of criminal justice policy in the Netherlands since World War II. The unprecedented rise in American imprisonment rates and changes in American criminal justice policies since 1973 have provoked a sizable literature that documents those developments, attempts to measure their effects, and tries to explain why what happened happened (e.g., Garland 2001; Tonry 2004a; Simon 2007). The stark rise in imprisonment and the harshening of English policies since 1993 have provoked similar literatures (e.g., Garland 2001; Ryan 2003; Tonry 2004b; Jones and Newburn 2006). The toughening of criminal justice practices in the Netherlands has been going on for as long as the American toughening, and much longer than the English. Neither of those countries, however, was ever regarded as an exemplar of enlightened criminal justice policies. How and why the Netherlands moved from exemplifying liberal to exemplifying repressive criminal justice policies is a story that has not yet fully been told.

\section{REFERENCES}

Aebi, Marcelo F., et al. 2006. The European Sourcebook of Crime and Criminal Fustice Statistics-2006. The Hague: Boom Juridische uitgevers.

Bijl, R. V., A. Zorlu, A. S. van Rijn, R. P. W. Jennissen, and M. Blom. 2005. Integratiekaart 2005. De maatschappelijke integratie van migranten in de tijd gevolgd: Trend- en cobortanalyses [Integration map 2005. The societal integration of migrants followed over time: Trend- and cohort analyses]. The Hague: WODC.

Bijleveld, Catrien. In this volume. "Sex Offenders and Sex Offending."

Bijleveld, Catrien, and Paul Smit. 2004. "Netherlands." In Cross-National Studies in Crime and Fustice, edited by David P. Farrington, Patrick A Langan, and Michael Tonry. Washington, DC: U.S. Department of Justice, Bureau of Justice Statistics.

- 2005. "Crime and Punishment in the Netherlands, 1980-1999." In Crime and Punishment in Western Countries, 1980-1999, edited by Michael Tonry and David P. Farrington. Vol. 33 of Crime and Justice: A Review of Research, edited by Michael Tonry. Chicago: University of Chicago Press.

Blokland, Arjan, and Paul Nieuwbeerta, eds. 2006. Developmental and Life Course Studies in Delinquency and Crime: A Review of Contemporary Dutch Research. The Hague: Boom Legal Publishers.

Blom, M., J. Oudhof, R. V. Bijl, and B. F. M. Bakker. 2005. Verdacbt van criminaliteit: Allocbtonen en autocbtonen nader bekeken [Suspected of an offense: Indigenous and nonindigenous Dutch scrutinized]. The Hague: WODC. 
Boutellier, Hans. 2005. The Safety Utopia: Contemporary Discontent and Desire as to Crime and Punishment. Dordrecht: Kluwer Academic.

Bruinsma, Gerben J. N. In this volume. "Urbanization and Urban Crime: Dutch Geographical and Environmental Research."

Buruma, Ian. 2006. Murder in Amsterdam: The Death of Theo van Gogh and the Limits of Tolerance. London: Penguin.

Buruma, Ybo. In this volume. "Dutch Tolerance: On Drugs, Prostitution, and Euthanasia."

Council of Europe. 1992. Council of Europe Annual Penal Statistics: 1990 Enquiry. Strasbourg: Council of Europe.

- 2001. Council of Europe Annual Penal Statistics: 1999 Enquiry. Strasbourg: Council of Europe.

- 2005. Council of Europe Annual Penal Statistics: Survey 2004. Strasbourg: Council of Europe.

Croes, Marnix, and Peter Tammes. 2004. "Gif laten wij niet voortbestaan": Een onderzoek naar de overlevingskansen van joden in de Nederlandse gemeenten, 1940-1945 [Poison shall not live on: A study of the survival chances of Jews in Dutch municipalities, 1940-1945]. Amsterdam: Aksant.

Downes, David. 1988. Contrasts in Tolerance: Post-war Penal Policies in the Netberlands and England and Wales. Oxford: Clarendon.

- 2007. "Visions of Penal Control in the Netherlands." In Crime and Fustice: $A$ Review of Research, vol. 36, edited by Michael Tonry. Chicago: University of Chicago Press.

Downes, David, and René van Swaaningen. In this volume. "The Road to Dystopia? Changes in the Penal Climate of the Netherlands."

Engbersen, Godfried, Joanne van der Leun, and Jan de Boom. In this volume. "The Fragmentation of Migration and Crime in the Netherlands."

Faber, Sjoerd. 1983. Strafrecbtspleging en criminaliteit de Amsterdam, 1680-1811 [Criminal justice and crime in Amsterdam, 1680-1811]. Arnhem: Gouda Quint.

Fijnault, Cyrille. 2007. De geschiedenis van der Nederlandse politie [The history of the Dutch police]. The Hague: Boom Juridische uitgevers.

Garland, David. 2001. The Culture of Control. Chicago: University of Chicago Press.

Ippel, Pieter, and Susanne Heeger. 2006. Sprekend de recbtbank [Court voices]. Utrecht: University of Utrecht.

Jones, Trevor, and Tim Newburn. 2006. Policy Transfer and Criminal Fustice. Milton Keynes, UK: Open University Press.

Junger-Tas, Josine. 2004. "Youth Justice in the Netherlands." In Youtb Crime and Youtb Fustice: Comparative and Cross-National Perspectives, edited by Michael Tonry and Anthony N. Doob. Vol. 31 of Crime and fustice: A Review of Research, edited by Michael Tonry. Chicago: University of Chicago Press.

Junger-Tas, Josine, Ineke Haen Marshall, and Denis Ribeaud. 2003. Delinquency in International Perspective-the International Self-Reported Delinquency Study. Monsey, NY: Criminal Justice Press. 
Junger-Tas, Josine, and Marianne Junger. In this volume. "The Dutch Criminological Enterprise."

Kaiser, Günther. 1984. Prison Systems and Correctional Laws: Europe, the United States, and Japan. New York: Transnational Publishers.

Kleemans, Edward R. In this volume. "Organized Crime, Transit Crime, and Racketeering."

Leuw, Ed. 1991. "Drugs and Drug Policy in the Netherlands." In Crime and 7ustice: A Review of Research, vol. 14, edited by Michael Tonry. Chicago: University of Chicago Press.

- 1999. Recidive na de tbs: Patronen, trends en processen en de inschatting van gevaar [Recidivism after TBS: Patterns, trends, and processes and risk assessment]. The Hague: WODC.

Loeber, Rolf, and Wim Slot. In this volume. "Serious and Violent Juvenile Delinquency: An Update."

Malsch, Marijke, and Hans Nijboer, eds. 1999. Complex Cases: Perspectives on the Netberlands Criminal fustice System. Amsterdam: Thela Thesis.

Nieuwbeerta, Paul. 2002. Crime Victimization in Comparative Perspective: Results from the International Crime Victims Survey, 1989-2000. The Hague: Boom Juridische uitgevers.

Nieuwbeerta, Paul, and Ingeborg Deerenberg. 2005. "Moord en doodslag in Nederland, 1911-2002" [Homicide in the Netherlands, 1911-2002]. Bevolkingstrends 53:56-63.

Ryan, Mick. 2003. Penal Policy and Political Culture in England and Wales. Winchester, UK: Waterside.

Simon, Jonathan. 2007. Governing through Crime. New York: Oxford University Press.

Tak, Peter J. 2001. "Sentencing and Punishment in the Netherlands." In Sentencing and Sanctions in Western Countries, edited by Michael Tonry and Richard S. Frase. New York: Oxford University Press.

. 2003. The Dutch Criminal fustice System: Organization and Operation. The Hague: WODC.

Tonry, Michael. 2004a. Tbinking about Crime: Sense and Sensibility in American Penal Culture. New York: Oxford University Press.

. 2004b. Punishment and Politics: Evidence and Emulation in the Making of Englisb Crime Control Policy. Cullompton, Devon, UK: Willan.

$\longrightarrow$, ed. 2007. Crime, Punishment, and Politics in Comparative Perspective. Chicago: University of Chicago Press.

van de Bunt, Henk, and Wim Huisman. In this volume. "Organizational Crime in the Netherlands."

van Dijk, Jan. 2006. "What Goes Up, Must Come Down: Explaining Falling Crime Rates." Criminology in Europe 5:1, 17-18.

van Dijk, Jan, Robert Manchin, John van Kesteren, and Gegerly Hideg. 2007.

The Burden of Crime in the EU. Tilburg, Netherlands: Intervict.

van Egmond, Florike. 1993. Organized Crime in the Netberlands, 1650-1800. Cambridge: Polity.

van Kesteren, John, Pat Mayhew, and Paul Nieuwbeerta. 2001. Criminal Vic- 
timisation in Seventeen Industrialised Countries: Key Findings from the 2000 International Crime Victims Survey. The Hague: WODC.

van Koppen, Peter J. 2003. De Schiedammer parkmoord: Een rechtspsycbologische reconstructie [The Schiedam park murder: A legal-psychological reconstruction]. Nijmegen: Ars Aequi Libri.

van Koppen, Peter J., and T. M. Schalken. 2004. "Rechterlijke denkpatronen als valkuilen: Over zes grote zaken en der zelver bewijs" Uudges' ways of thinking as pitfalls: Six large cases and their proof]. In Het Maatschappelijk oordeel van de strafrecbter [The social judgment of the criminal judge], edited by Jan de Keijser and Henk Elffers. The Hague: Boom Juridische uitgevers. van Ruller, Sibo, and Guillaume Beijers. 1995. "De gevangenisstatistiek in het licht van de geschiedenis" [Prison statistics in historical perspective]. Fustitiële Verkenningen 21:35-52.

van Swaaningen, René. 2006. "Criminology in the Netherlands." European Journal of Criminology 3(4):463-501.

Verhagen, Jos L. M. 2005. Waar vrijbeid ophoudt en weer kan beginnen [Where freedom ends and can restart]. The Hague: Dienst Justitiële Inrichtingen.

Weerman, Frank M. In this volume. "Juvenile Offending."

Wittebrood, Karin, and Paul Nieuwbeerta. 2006. "Een kwart eeuw stijging in geregistreerde criminaliteit: Vooral meer registratie, nauwelijks meer criminaliteit" [A quarter century of rising registered crime: Mainly more registration, hardly more crime]. Tijdschrift voor Criminologie 48:227-42. 